JPPIPA, Vol.6 No.1 2021
Jurnal Penelitian Pendidikan IPA
http://journal.unesa.ac.id/index.php/jppipa

\title{
ANALYSING TRADITIONAL ISLAMIC BOARDING SCHOOL STUDENTS' SCIENTIFIC LITERACY USING PISA FRAMEWORK
}

Munasprianto Ramli ${ }^{1}$, Nanda Saridewi ${ }^{2}$, Abdul Rifki ${ }^{3}$

${ }^{1,2,3}$ Program Studi Pendidikan Kimia, Fakultas Ilmu Tarbiyah dan Keguruan, Universitas Islam Negeri Syarif Hidayatullah Jakarta, Indonesia

\begin{abstract}
The study aims to determine the scientific literacy ability of class IPA $11^{\text {th }}$ grade students at traditional Islamic boarding schools using the 2015 PISA framework. Descriptive quantitative method used for this research. The research was conducted at two traditional Islamic boarding schools in South Tangerang called the Jamiyah Islamiyah Islamic Boarding School and the Madinatunnajah Islamic Boarding School. The research sample consisted of 57 students consisting of 33 students of the Jamiyah Islamiyah Islamic Boarding School and 24 students of the Madinatunnajah Islamic Boarding School chosen using a purposive sampling technique. The written test used is a test that distributed at PISA 2012 and 2015 which focus on two main domains of PISA 2015 scientific literacy, namely the domain of competence and knowledge. The results of this study indicate that the scientific literacy skills of students in Islamic boarding schools using the 2015 PISA framework are still "low" with an average percentage of scientific literacy obtained of $29.03 \%$.
\end{abstract}

Keywords: 2015 PISA Framework, Islamic Boarding School, Science Literacy

(C) 2021 Universitas Negeri Surabaya 


\section{INTRODUCTION}

Education is one area that is very important in improving the quality of human resources (HR). Without education, of course, humans will be left behind in the aspect of science and technology. Education is a process with a variety of methods that help individuals to acquire knowledge, understanding, perspective, and behave in accordance with situation (Shah 2010: 10). According to the Law Article 1 number 20 of 2003 on National Education System (Education) stated that the national education system is the whole educational component that is integrated and relates to each other to achieve national education goals ( RI Law No.20 of 2003: 1). In the 21st century, SISDIKNAS has faced challenges in preparing quality human resources that can compete in that era. One of the right efforts in preparing quality human resources and being able to build high-quality human resources is education (Trianto, 2009: 4).

Scientific literacy-based learning is the main thing in education in the 21 st century for the development of the nation. Scientific literacy is one of the important skills that must be possessed by students. On an international scale, students' scientific literacy skills are measured by the Program for International Student Assessment (PISA) conducted by the Organization for Economic Co-operation and Development (OECD) every three years. According to PISA (2015), Scientific Literacy is the ability to engage with science-related issues, and with the ideas of science, as a reflective citizen. " (OECD, 2013). Meanwhile, scientific literacy based on the National Science Education Standards (1996) is " scientific literacy is knowledge and understanding of scientific concepts and processes required for personal decisions on making, participation in civic and cultural affairs, and economic productivity. It also includes specific types of abilities".

As the assessment standards conducted globally, the framework and concept of scientific literacy that was developed by PISA changes overtime. In 2015, PISA defined scientific literacy framework into 4 domains namely context, competence, knowledge and attitudes. The researchers focus on two main domain that are competence and knowledge. PISA 2015 defined competency domains into three aspects, namely competence that explain the phenomenon scientifically, evaluate and design a scientific investigation, and interpretation of data and scientific evidence. While knowledge domain 's divided into three aspects namely content knowledge, procedural knowledge, and knowledge epistemic (OECD, 2015).

The scientific literacy of Indonesian students is still relatively low. It can be seen from the results of the PISA assessment conducted by the OECD. Indonesia was ranked 38th out of 41 countries (2000), ranked 38th out of 40 countries (2003), ranked 50th out of 57 countries (2006), ranked 60 th out of 65 countries (2009), ranked 64th out of 65 countries (2012), and ranked 62 out of 70 countries (2015) (OECD, 2003; 2004; 2007; 2010; 2014; and 2018). From the results of the newly released PISA report-PISA 2018, it is stated that scientific literacy skills have decreased compared to the 2015 PISA results of 396, far below the OECD average score of 489 with a rank of 70 out of 78 countries (OECD, 2019a). Based on the ability level of the PISA assessment criteria, approximately $40 \%$ of Indonesian students achieve level 2 or higher in science (OECD average $78 \%$ ) (OECD, 2019b).

Based on the data from the PISA results, it can be said that the ability of scientific literacy in Indonesia is still relatively low. Some studies (Arief 2015, Ramli 2021) mentioned that it influenced by several factors, among others, students have not been accustomed to solving problems based scientific literacy, it is because students are more accustomed to memorizing material learner 's compared with understand the learning material, so that it is difficult for students to understand the material and apply the material in everyday life. The next factor is because students tend not to like to answer questions in the form of descriptions and prefer to answer in the form of multiple choices, this is because the teacher gives questions for learning evaluation that are not yet a matter of analysis, so students have not been able to use their reasoning (Huryah et al ., 2017).

Likewise, Angraini's research ( 2014) which states that there are 3 factors that cause students' scientific literacy to be low. The first factor is that students have difficulty in answering questions based on scientific literacy because students have never studied it. The second factor is because in the process of teaching and learning activities (KBM) teachers do not develop students' scientific literacy skills. And the third factor is that students are not used to solving problems using discourse.

In times of industry revolution 4.0, one of the skills that must be possessed by students is scientific literacy. This scientific literacy will be possessed in the science learning process in schools, including in the boarding school 
environment. Pondok Pesantren as one of the oldest Islamic educational institutions in Indonesia is considered to be able to play a vital role in the effort to provide education for the people of Indonesia. History has shown that pesantren is present in the midst of society not only as educational institutions, but also more than that. Pesantren is also a social and religious broadcasting institution (Zulhimma, 2013). Education in pesantren has its own characteristics where religion is put forward among others. It's very different from other educational institutions, so that the learning of science in schools is not overstated.

Science learning includes chemistry, physics and biology. Based on Fauzi's research (2016), chemistry in pesantren, namely Amanatul Ummah Senior High School, are studied by the students for 6 semesters with 38 basic competencies. Chemistry at this Islamic boarding school contain a lot of material that is quite difficult to learn and also the material is abstract, it makes students at this Islamic boarding school have difficulty understanding and understanding the subject matter of chemistry. This is evidenced by the results of student tests at the Islamic boarding school which has decreased by $40 \%$ compared to other materials. In addition, this study also shows that teachers tend to use the lecture method during the chemistry learning process in the classroom, compared to using a scientific approach and not even teaching the material contextually.

The pesantren education system continues to be developed, the development of the education system has followed the pattern of national education. Education that is developed in the form of study materials has also followed the times, not only the department of religion but has developed the Department of Natural Sciences (IPA) and is ready to be competent with educational institutions both nationally and internationally. With the existence of science majors and learning in Madrasahs, researchers feel the need to conduct research on the scientific literacy abilities of Islamic boarding school students. Considering that the data available from PISA is general, without specifying the origin of school, then researchers want to conduct a research under the title "Analysis Capabilities Science Literacy Students at boarding using the framework PISA 2015". This study aims to determine the scientific literacy ability of students in Islamic boarding schools using the 2015 PISA framework.

\section{METHOD}

The research method used by the researcher in this study is a quantitative method with a descriptive approach. In this study, a description of the scientific literacy skills of students in Islamic boarding schools located in South Tangerang will be described. Where the scientific literacy is described in quantitative data by looking at scientific literacy score of students obtained from the students' answers on the test item descriptions using the framework PISA 2015.

The objects of this study were 33 students of class XI IPA at Pondok Pesantren Jamiyah Islamiyah, South Tangerang and 24 students at Pondok Pesantren Madinatunnajah, South Tangerang, class of the 2019/2020 academic year.

The instrument used in this study is a written test scientific literacy. Researchers used 15 pieces about the description taken from the PISA 2012 and PISA 2015 with regard domain competence and knowledge in the framework of PISA 2015. Those items were adapted from OECD PISA, so that the validity and reliability are guaranteed by the Institute .

The data collection technique used is a description test. This test is a set of questions that measure the ability of an individual or groups, measure skills, and measuring knowledge (Arikunto, 2013: 193). The test is used to determine the scientific literacy ability of students in Islamic boarding schools.

Data obtained in this research were analysed to determine the literacy skills of science of the students at the boarding school based on written tests using $a$ framework PISA 2015. The data obtained were analyzed by calculating the percentage of the literacy skills of each student's science. The percentage of scientific literacy ability is interpreted into the PISA test score criteria.

Table 1. Criteria for Interpretation of PISA Test Scores

\begin{tabular}{cc}
\hline Interval & Criteria \\
\hline $0-20 \%$ & Very low \\
\hline $20-40 \%$ & Low \\
\hline $40-60 \%$ & Enough \\
\hline $60-80 \%$ & High \\
\hline $80-100 \%$ & Very high \\
\hline & (Riduwan, 2012: 89)
\end{tabular}




\section{RESULTS AND DISCUSSION}

Based on research that has been carried out in two Islamic Boarding Schools in South Tangerang City, namely Pondok Pesantren Jamiyah Islamiyah and Pondok Madinatunnajah. The implementation is carried out during chemistry lesson hours in each Islamic boarding school. All students were given the test in the span of a twohour lesson. From the results obtained, the researchers saw differences in the results of each Islamic boarding school. These results can be viewed on $\mathrm{G}$ amber 1 below.

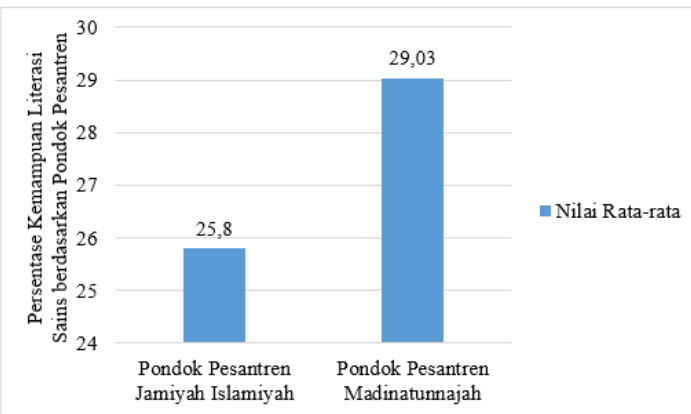

Figure 1. Scientific Literacy in Islamic Boarding Schools

Figure 1 is showing scientific literacy skills in Islamic boarding schools. Based on these data, it can be seen that the average score obtained by students at the Jamiyah Islamiyah Islamic Boarding School is 25.8. This shows that the scientific literacy of students in boarding schools are still relatively low. While the average value of the results obtained by students at Madinatunnah ois 29.03 it is also shows that the literacy skills of students is still relatively low. In accordance with Angraini's research (2014) that students' scientific literacy skills are in the very low category with an average score of 27.94. Correspondingly, Nur'aini et al., (2018) also describes that the scientific literacy of Indonesian students is still relatively low. According to a hypothesis test has been carried obtained results that $\mathrm{H}_{0} 0$ was accepted and Ha was rejected. This indicates that there is no significant difference between the average scientific literacy skills of students at the Khalafi Islamic Boarding School (Madinatunnajah) and students at the Salafi Islamic Boarding School (Jamiyah Islamiyah). Many factors cause the low score of scientific literacy, among others, students are not accustomed to solving questions based on scientific literacy, this is because students are more accustomed to memorizing subjects compared to understanding learning materials, so it is difficult for students to understand the material and apply the material they get in the classroom in everyday life. The next factor is because students prefer to answer questions in the form of multiple choice than in the form of descriptions, this is because the teacher giving questions for learning evaluation is not yet a matter of analysis, so students have not been able to use their reasoning (Huryah et al., 2017). In addition, according to Kurnia et al., ( 2014) it is also influenced by several factors including learning facilities and facilities, learning resources, teaching materials as well as the selection of models and learning methods. One of the factors experienced in Islamic boarding schools is the lack of inadequate facilities and infrastructure, such as laboratories. Basically, the laboratory is very important in learning science or science, especially chemistry because the laboratory is a place where to prove theories obtained through practical activities, so that students can prove the theories obtained in the teaching learning process through practical activities (Emda, 2014) .

According to Gloria's research (2014) from the interviews, that science practicum activities at Boarding School of As-Sunnah Cirebon are very rarely carried out, even though students' interest in practical activities is quite good, although almost no one likes to do practical activities. This shows that students at the Islamic boarding school basically have a desire to carry out science learning with practicum, not just studying science theoretically. One of the obstacles experienced by As-Sunnah Islamic Boarding School in science practicum activities is the absence of inadequate laboratory facilities, such as Chemistry, Biology and Physics laboratories.

Practical activities in science learning are believed to be able to improve aspects of students' scientific literacy such as process aspects, scientific attitudes and content (Arisman \& Permanasari, 2015). In addition, according Rizkita et al., (2016) learning strategies Problem-Based Learning (PBL) also may help improve the scientific literacy of students and the development of students' problem-solving skills. Then, the capacity of scientific literacy can also be improved through learning scientifically, because in the learning process, it can generate interest students in scientific issues, enhance students' understanding of the scientific process and students can foster a sense of responsibility for surrounding environment (Asyhari \& Hartati, 2015). This shows that increasing scientific literacy skills can be done with the right learning process in the classroom. One of the appropriate learning models to develop scientific literacy is like learning using Guided Inquiry (Istiqomah \& Hariyono, 2019), Conceptual Understanding 
Procedures (Amri et al., 2017), Learning Cycle 7E (Qulud et al., 2015), Guided Discovery Learning (Darwis et al., 2019) as well as contextual-based guided inquiry (Anggraeni et al., 2020).

In accordance with the 2015 PISA Framework , the scientific literacy ability of students analyzed in the competency domain consists of three indicators, namely students are able to explain scientific phenomena, students can interpret scientific data and evidence and students are skilled in evaluating and designing scientific investigations. Data on students' scientific literacy skills in the aspect of competence $\mathrm{i}$ are presented in Table 2.

Table 12 . Scientific Literacy in Competency Aspect

\begin{tabular}{lccc}
\hline \multicolumn{1}{c}{ Competency Aspect } & Maximum Value & Average value & Criteria \\
\hline Explaining phenomena scientifically & 77.77 & 33.33 & Low \\
$\begin{array}{l}\text { Interpreting scientific data and } \\
\text { evidence }\end{array}$ & 36.36 & 18.18 & Very low \\
$\begin{array}{l}\text { Evaluating and designing scientific } \\
\text { investigations }\end{array}$ & 100 & 50 & Enough \\
\hline
\end{tabular}

Based on Table 2, it is shown that students who achieve scientific literacy competence in Islamic boarding schools use the PISA framework 2015 with the highest percentage achieved on indicators of Evaluating and designing scientific investigations and followed by Explaining phenomena scientifically and Interpreting scientific data and evidence .

As many as $33.33 \%$ of students who mastered competence on indicators explaining phenomena scientifically and included in the category of "low" achievement, below that achievement only $18.18 \%$ of students mastered competence on aspects of interpreting data and scientific evidence and included in the category " very low", and as many as $50 \%$ of students who mastered competence in the indicators of evaluating and designing scientific investigations and included the category of "enough" achievement. Based on the analysis, it shows that students still have not been able to interpret the data and scientific evidence, and still less able to describes the phenomenon scientifically based answer answers they provide.

Based on the average score on the overall competency aspect, students get an average score of 33.83 and are included in the "low" achievement category. This is in accordance with the research of Andriani, Saparini, and Akhsan ( 2018) which concludes that when viewed from the competence of the science process, students' scientific literacy skills are still relatively low with an average value of 47.1. Then, if you look at the achievement in the aspect of student competence with a value of 33.83 , it means that students still have not dominated the competencies being tested. The low aspect of this competence is caused due to the limited her students' ability to identify the assorted variable as a survey of the scientific, because the process of the students learning is constantly assisted by teachers to determine a wide range of variables, including variable control, variable-bound and variable-free (Arief, 2015).

First competence being analysed is the ability of students to describe phenomena scientifically. From this indicator, it is expected that students were able to recall knowledge of the content that is appropriate in a given situation and use it to interpret and explain the phenomenon properly; generate explanatory hypotheses and models; identify appropriate descriptions and predictions (OECD, 2013). In this indicator, the maximum achievement that students can achieve in explaining the phenomenon scientifically is 77.77 of the 9 questions tested with the "high" achievement category. Meanwhile, the average value of scientific literacy in this aspect is 33.33 and is considered "low". This is in accordance with the research of Arding and Atun (2020) that the indicator explains the phenomenon scientifically by 32.19 and also in the research of Ariska and Rosana ( 2020) that this indicator obtained a value of 42.8 and is included in the medium category.

One of the low abilities on these indicators is that students still do not understand related scientific phenomena such as the phenomenon of acid rain, the greenhouse effect so that students are less able to explain scientific phenomena and relate them in their daily lives. This is revealed in the research of Nadhifatuzzahro, Seiawan, and Sudibyo ( 2015) that the low ability on this indicator is the lack of knowledge about scientific concepts and connecting the knowledge gained in everyday life.

In the second competency indicator, which is interpreting data and evidence scientifically, in which students must be able to analyze data in a graph and draw scientific conclusions appropriately (Rohmi, 2017) . In this indicator, the maximum achievement that students can achieve in interpreting data and scientific evidence is 36.36 of the 5 questions tested with the 
achievement category "enough". Meanwhile, the average value of scientific literacy in the aspect of interpreting data and scientific evidence obtained is 18.18 and is considered "very low". This agrees with the research of Aryani, Suwono and Pano (2016) that the competence aspect of scientific literacy that is at least controlled by students is interpreting data and evidence scientifically, which is 13.33 . This can be interpreted that in this indicator students are still less trained in interpreting data and making appropriate conclusions.

This indicator is influenced by one of the factors, namely textbooks that are lacking in conveying the main issues that require students to think, lack of insight into the application of science concepts to everyday life and lack of presenting strategies on problem solving (Winarti et al. al., 2016) . According to Rohmi (2017) the inquiry lab can train on this indicator, where the inquiry lab students are trained to analyze a table of experimental data, students are also trained to interpret it and students draw conclusions based on the results of the experimental data they get. This is due to the absence of a laboratory in Islamic boarding schools which makes students at Islamic boarding schools during learning not do practical activities, so students at Islamic boarding schools have not been trained in interpreting data from practicum/experimental results, students are also not accustomed to communicating experimental data and writing conclusions. obtained from experimental data.

In the third competency indicator, namely evaluating and designing scientific investigations, in which students must be able to evaluate the quality of data, which in turn depends on the recognition that data is not always completely accurate. It also requires competence to identify whether an inquiry is driven by an underlying theoretical premise or, alternatively, whether it seeks to define an identifiable pattern (OECD, 2013). In this indicator, the maximum achievement that students can achieve in evaluating and designing scientific investigations is 100 out of 1 questions tested with the achievement category "very high". While the average value of scientific literacy in the aspect of evaluating and designing scientific investigations obtained is $50 \%$ and includes "enough". The results of this study are similar to that of Safitri and Mayasari ( 2018) that the indicator evaluating and designing scientific investigations is $80.83 \%$ in the "high" category. Judging by the results of research conducted by Rohmi (2017) that $50 \%$ of students on the indicators of evaluating and designing scientific investigations, students do not experience difficulties in answering the questions given, where $50 \%$ of other students still have difficulties with this indicator. According to his research, students have difficulty because of the influencing factors, namely lack of practice, lack of training in determining experimental variables, and lack of opportunities for students to design their own experiments.

Science literacy skills of students analysed in the domain of knowledge consists of three indicators of knowledge procedural, knowledge content and knowledge epistemic. Data of scientific literacy of students in the domain of knowledge can be seen in Table 3 .

Table 3. Scientific Literacy in Knowledge Aspect

\begin{tabular}{cccc}
\hline Knowledge Aspect & Maximum Value & Average value & Criteria \\
\hline Content & 64.70 & 17.64 & Very low \\
Epistemic & 87.50 & 62.50 & High \\
Procedural & 33.33 & 16.66 & Very low \\
\hline
\end{tabular}

According to Table 3, it is shown that students who achieved the knowledge aspect of scientific literacy in Islamic boarding schools used the 2015 PISA framework with the highest percentage achieved in the epistemic knowledge indicator which was then followed by content knowledge and procedural knowledge.

A total of $17.64 \%$ of students who mastered content knowledge and included in the "very low" achievement category, as many as $62.5 \%$ of students who mastered epistemic knowledge and were included in the "high" category, and under that achievement only 16.66 students who mastered procedural knowledge and included in the category of "very low" achievement. These results indicate that the ability of students to answer questions on indicators of content knowledge and procedural knowledge is still quite limited. Many students answered incorrectly on these indicators, even a few students chose to leave the answers blank for the questions being tested.

Then, when viewed as a whole from the average value in the aspect of knowledge, students get an average score of 32.26 this is certainly included in the "low" category. The results of this study are in line with the research of Aryani, Suwono, and Parno (2016) which shows that the knowledge aspect is still relatively low with a value of $34 \%$. When viewed from the achievement 
of the knowledge aspect of students with a value of 32.26, it means that students still have not dominated the competencies being tested.

The first knowledge indicator is content knowledge, where content knowledge at PISA 2015 includes physics, chemistry, biology, and earth and space sciences (OECD, 2013). This knowledge is knowledge of facts, concepts, ideas, and theories about the universe as established in science (Abidin et al., $2017: 147$ ). In this indicator, the maximum achievement that students can achieve in content knowledge is 64.70 of the 9 questions tested with the "high" achievement category. Meanwhile, the value obtained on procedural knowledge is 17.64 and includes "very low". The results of this study are not much different from the research of Nofiana and Juliyanto (2017) which shows that the content aspect is still in the low category with a value of 43.56. So that the content knowledge possessed by students is still lacking in various fields such as the theory of acid rain and the greenhouse effect.

In the second knowledge indicator, namely procedural knowledge, students were tested related to research knowledge, such as minimizing errors with repeated measurements, controlling variables and trying to reduce uncertainty and using standard procedures to present and present data (Abidin et al., 2017: 147). In this indicator, the maximum achievement that students can achieve in procedural knowledge is 33.33 of the 2 questions tested with the achievement category "enough". Meanwhile, the average value of scientific literacy in the aspect of procedural knowledge obtained is 16.66 and is considered "very low". This is in accordance with the research of Pahrudin et al., (2019) that procedural knowledge is still relatively low with a score of 42. His research reveals that this lack of ability is caused by the inability to identify experimental variables and explore knowledge.

The third knowledge indicator is epistemic knowledge. In this indicator, the maximum achievement that students can achieve in content knowledge is 87.50 of the 4 questions tested with the achievement category "very high". Meanwhile, the average value of scientific literacy in the aspect of procedural knowledge obtained is 62.5 and includes "high". The results obtained by students on content knowledge and procedural knowledge are inversely proportional to epistemic knowledge which shows quite good results. This means that students are able to provide arguments in science which are quite good when solving the problems being tested.

Finally, for the context domain based on the 2015 PISA framework, there are three indicators, namely global, personal and local/national.
However, in this study, the questions tested were questions with a global context. Based on the average value in the context aspect, the average value is 29.03 and is classified as "low". As with the research of Subaidah et al., (2019) which revealed that scientific literacy skills in the context aspect were very poor with a value of $37 \%$. According to this study, this condition was triggered by science learning which emphasizes mastery of concepts and does not provide space for the development of application of concepts (context). In addition, another study conducted by Nofiana and Julianto (2017) concluded that scientific literacy skills in the context aspect are still very low with a value of 32.14. According to his research, teachers tend to provide material without relating it to real life, this condition then makes it difficult for students to apply what they learn in class into their daily lives.

\section{CONCLUSION}

Based on the results of the analysis of research data and the discussion that the researchers have presented above, it can be concluded that the scientific literacy ability of students in Islamic boarding schools using the 2015 PISA framework is still relatively "low" with an average percentage of scientific literacy obtained by students of $29.03 \%$.

\section{SUGGESTION}

The researchers' suggestions based on the findings of this study are as follows:

1. Islamic boarding schools should provide adequate and supportive facilities in developing scientific literacy skills, such as laboratories, student reading resources.

2. For teachers, they should develop students' scientific literacy skills in teaching and learning activities in Islamic boarding schools.

3. For students, they should get used to understanding a science concept and try to apply it in everyday life and get used to practicing on questions based on scientific literacy.

\section{REFERENCES}

Abidin, Y., Mulyati, T., \& Yunansyah, H. (2017). Pembelajaran Literasi Strategi Meningkatkan Kemampuan Literasi Matematika, Sains, membaca, dan Menulis. Bumi Aksara.

Amri, M. Y. B., Rusilowati, A., \& Wijayanto. (2017). Penerapan Model Pembelajaran Conceptual Understanding Procedures untuk Meningkatkan Kemampuan Literasi 
Sains Siswa SMP di Kabupaten Tegal. Unnes Physics Education Journal, 6(3), 81-93.

Andriani, N., Saparini, \& Akhsan, H. (2018). Kemampuan Literasi Sains Fisika Siswa SMP Kelas VII Di Sumatera Selatan Menggunakan Kerangka PISA ( Program for International Student Assesment ). Berkala Ilmiah Pendidikan Fisika, 6(3), 278-291. https://doi.org/10.20527/bipf.v6i3.5288

Anggraeni, A. Y., Wardani, S., \& Hidayah, A. N. (2020). Profil Peningkatan Kemampuan Literasi Kimia Siswa Melalui Pembelajaran Inkuiri Terbimbing Berbasis Kontekstual. Jurnal Inovasi Pendidikan Kimia, 14(1), 2512-2523.

Angraini, G. (2014). Analisis Kemampuan Literasi Sains Siswa SMA Kelas X di Kota Solok. Prosiding Mathematics and Sciences Forum 2014, 161-170.

Arding, N. I., \& Atun, S. (2020). Analysis of Junior High School Students 'Scientific Literacy On Simple Effort and Aircraft For Everyday Life. Journal of Physics: Conference $\quad$ Series, 1-7. https://doi.org/10.1088/17426596/1440/1/012095

Arief, M. K. (2015). Penerapan Levels Of Inquiry Pada Pembelajaran IPA Tema Pemanasan Global Untuk Meningkatkan Literasi Sains. 2(2).

Arikunto, S. (2013). Prosedur Penelitian Suatu Pendekatan Praktik. PT Rineka Cipta.

Ariska, I., \& Rosana, D. (2020). Analysis of Junior High School Scientific Literacy Skills: Domain Competence On Vibrations, Waves and Sound Materials. Journal of Physics: Conference Series, 17. 6596/1440/1/012094

Arisman, A., \& Permanasari, A. (2015). Penerapan Pembelajaran Kooperatif Tipe Stad Dengan Metode Praktikum Dan Demonstrasi Multimedia Interaktif (MMI) Dalam Pembelajaran Ipa Terpadu Untuk Meningkatkan Literasi Sains Siswa. Edusains, 7(2), 179-184.

Aryani, A. K., Suwono, H., \& Parno. (2016). Profil Kemampuan Literasi Sains Siswa SMPN 3 Batu. Pros. Semnas Pendidikan IPA Pascasarjana UM, 1, 847-855.

Asyhari, A., \& Hartati, R. (2015). Profil Peningkatan Kemampuan Literasi Sains Siswa Melalui Pembelajaran Saintifik. Jurnal Ilmiah Pendidikan Fisika AlBiRuNi, 04(2), 179-191. https://doi.org/10.24042/jpifalbiruni.v4i2.9
1

Council, N. R. (1996). National Science Education Standars. National Academy of Science. https://doi.org/10.17226/4962

Darwis, D., Permatasari, N. A., \& Nurjayadi, M. (2019). Pengaruh Model Pembelajaran Guided Discovery Learning Terhadap Literasi Kimia Peserta Didik pada Materi Larutan Penyangga. Jurnal Riset Pendidikan Kimia, 9(2), 67-71. https://doi.org/https://doi.org/10.21009/JRP K.092.02 Pengaruh

Emda, A. (2014). Laboratorium Sebagai Sarana Pembelajaran Kimia Dalam Meningkatkan Pengetahuan dan Ketrampilan Kerja Ilmiah. 2(2), 218-229.

Fauzi, A. (2016). Implementasi Strategi Relating, Experiencing , Applying , Cooperating , Transferring (REACT) Untuk Meningkatkan Penguasaan Konsep Siswa Pada Materi Pokok Larutan Penyangga Di Sekolah Berbasis Pesantren. Prosiding Seminar Nasional Kimia Dan Pembelajarannya, September, 92-97.

Gloria, R. Y. (2014). Kajian Penilaian Aspek NonKognitif Siswa di Pesantren As-sunnah dalam Kegiatan Praktikum IPA Pokok Bahasan Sistem Pencernaan Pada Manusia. Jurnal Phenomenon, 4, 95-107.

Huryah, F., Sumarmin, R., \& Effendi, J. (2017). Analisis Capaian Literasi Sains Biologi Siswa SMA Kelas X di Kota Padang. Jurnal Eksata Pendidikan, 1(2), 72-79. https://doi.org/10.24036/jep.v1i2.70

Istiqomah, C. Z., \& Hariyono, E. (2019). Peningkatan Literasi Sains Siswa Dengan Menggunakan Model Pembelajaran Guided Inquiry. Inovasi Pendidikan Fisika, 08(02), 682-685.

Kurnia, F., Zulherman, \& Fathurohman, A. (2014). Analisis bahan ajar fisika sma kelas xi di kecamatan indralaya utara berdasarkan kategori literasi sains. Jurnal Inovasi Dan Pembelajaran Fisika, 1(1), 43-47.

Nadhifatuzzahro, D., Setiawan, B., \& Sudibyo, E. (2015). Kemampuan Literasi Sains Siswa Kelas VII-B SMP Negeri 1 Sumobito Melalui Pembuatan Jamu Tradisional. Seminar Nasional Fisika Dan Pembelajarannya 2015, 21-27.

Nofiana, M., \& Juliyanto, T. (2017). Profil Kemampuan Literasi Sains Siswa SMP di Kota Purwokerto Ditinjau Dari Aspek Konten, Proses, dan Konteks Sains. Jurnal Sains Sosial Dan Humaniora, I(September), 77-84.

Nur'aini, D., Rahardjo, S. B., \& Susanti, E. 
(2018). Student's profile about science literacy in Surakarta. Journal of Physics: Conference Series, 1-6.

OECD. (2003). Literacy Skills for the World of Tomorrow Further Results From PISA 2000. OECD Publishing.

OECD. (2004). Learning for Tomorrow's World First Results from PISA 2003. OECD Publishing.

OECD. (2007). PISA 2006 Science Competencies For Tomorrow's World Volume 1:Analysis. OECD Publishing.

OECD. (2010). PISA 2009 Results: Executive Summary. OECD Publishing.

OECD. (2013). PISA 2015 Draft Science Framework. OECD.

OECD. (2014). PISA 2012 Results in Focus. OECD Publishing.

OECD. (2018). Pisa 2015 Result in Focus. OECD Publishing.

OECD. (2019a). PISA 2018 Results Combined Executive Summaries Volume I, II \& III. OECD Publishing.

OECD. (2019b). Programme For International Student Assessment (PISA) Results From PISA 2018 (pp. 1-10). OECD Publishing.

Pahrudin, A., Irwandani, Triyana, E., Oktarisa, Y., \& Anwar, C. (2019). The Analysis Of PreService Physics Teachers In Scientific Literacy: Focus On The Competence And Knowledge Aspects. Jurnal Pendidikan IPA Indonesia, 8(1), 52-62. https://doi.org/10.15294/jpii.v8i1.15728

Qulud, Wahidin, \& Maryuningsih, Y. (2015). Penerapan Model Pembelajaran Learning Cycle 7e Untuk Meningkatkan Kemampuan Literasi Sains Siswa Pada Konsep Sistem Reproduksi Kelas Xi Di SMA Negeri 1 Arjawinangun. Scientiae Educatia, 5(1).

Ramli, M., Susanti B,H., Yohana, M \& Rozak, A. (2021). Assessing Islamic junior high schools students' scientific literacy using PISA released items. Journal of Physics:
Conference Series Volume : 1836, 1-7

Riduwan. (2012). Belajar Mudah Penelitian Untuk Guru - Karyawan dan Peneliti Pemula. Alfabeta.

Rizkita, L., Suwono, H., \& Susilo, H. (2016). Analisis Kemampuan Awal Literasi Sains Siswa SMA Kota Malang. Prosiding Seminar Nasional II Tahun 2016, 771-781.

Rohmi, P. (2017). Peningkatan Domain Kompetensi Dan Pengetahuan Siswa Melalui Penerapan Levels Of Inquiry Dalam Pembelajaran Ipa Terpadu. Edusains, 9(1), 14-23.

Safitri, Y., \& Mayasari, T. (2018). Analisis Tingkat Kemampuan Awal Siswa SMP / MTS Dalam Berliterasi Sains Pada Konsep IPA. Seminar Nasional Quantum, 25, 165170.

Subaidah, T., Muharrami, L. K., Rosidi, I., \& Ahied, M. (2019). Analisis Kemampuan Literasi Sains Pada Aspek Konteks Dan Knowledge Menggunakan Cooperative Proplem Solving (CPS) Dengan Strategi Heuristik. Natural Science Education Research, 2(2), 113-122.

Syah, M. (2010). Psikologi Pendidikan dengan Pendekatan Baru. PT Remaja Rosdakarya.

Trianto. (2009). Mendesain Model Pembelajaran Inovatif-Progresif: Konsep, Landasan, dan Implementasinya pada Kurikulum Tingkat Satuan Pendidikan (KTSP) edisi pertama. Prenada Media Group.

Undang-undang RI No. 20 Tahun 2003 Tentang Sistem Pendidikan Nasional. (2003). Depdiknas.

Winarti, W., Liliawati, W., Rusnayati, H., \& Sari, I. M. (2016). Literasi Sains Siswa SMP di Kota Bandung Pada Tema Alam Semesta. Pros. Semnas Pendidikan IPA Pascasarjana UM, 1, 501-505.

Zulhimma. (2013). Dinamika Perkembangan Pondok Pesantren Di Indonesia. Jurnal Darul 'Ilmi, 01(02), 165-181. 